\title{
Refusing the world: silence, commoning and the Anthropocene
}

\author{
Anja Kanngieser (University of Wollongong) \\ Nicholas Beuret (Lancaster Environment Centre)
}

\begin{abstract}
This paper establishes silence as an ethical-political response to the Anthropocene. Silence, in this paper, is key to the making of commons, which frames the reinvention of ways of living and relating as a necessary response to the Anthropocene moment. Drawing from and intervening in autonomist Marxist debates on communicative labour, recent interdisciplinary work on Anthropocene ecologies and writing on the violences of ongoing colonialism, it shows how silence in its diverse forms can be used to expand what commons might mean, and what they might come to do in the present era. Mindful of the ambivalences of silence, it contends that the tensions inherent to its politics foster the suspension of assertions on how the world is, or how it should be. In this way, silence is argued as crucial to making spaces in which the proliferation of different ways of being can occur, and from within which resistance against forms of cognitive capitalism, neocolonialism and the ecological destruction of the earth can take place.
\end{abstract}

Keywords: silence, commoning, cognitive capitalism, ecology, colonialism

\author{
Introducing silence ${ }^{1}$ \\ Silence can be a plan \\ rigorously executed \\ the blueprint of a life \\ It is a presence \\ it has a history a form \\ (Rich 1978: 5)
}

The meteoric rise of the Anthropocene as a device for thinking through the slow, ongoing ecological disasters that mark the current period speaks to a pervasive catastrophism within political and ecological praxis. The Anthropocene operates as a call to action: it describes a series of complex emergencies that require urgent response on unimaginable scales. From the truncated timelines of climate change ('we have only 100 months to act!') to the vastness of the Sixth Great Extinction (Kolbert 2014), the Anthropocene is an epoch of heroic activity. 
The calls to ecological heroism - the injunction to recreate humanity as a global steward (Steffen et al 2011) or the calls to engineer the Earth (Lynas 2011) - have not gone uncontested. But whereas much of the current debate on the concept of the Anthropocene takes issue with the locus of human capacity for geological agency (Crist 2013; Haraway 2015), we question the call to action itself. If action here designates a project to 'save the world', or at the very least sustainably manage it, we contend that radical politics in the Anthropocene needs to turn to silence as an overlooked component of ethico-political thought. Indeed, we would suggest that the Anthropocene forces us to think silence, to work through the tensions it introduces into political life in the contemporary moment.

Cognizant of the indistinct nature of silence as a concept, we want to explore its constituent role as an element of political praxis. Specifically, if the political challenge of the Anthropocene is how to constitute the world amongst the ruins of the Holocene, silence suggests a means of breaking with the concept of the global environment as a unitary space of human species-action and engendering a series of 'other worlds' through the practice of commoning. Taking up a particular articulation of commoning that draws on the autonomist perspective associated with the US collective Midnight Notes and the UK-based journal The Commoner (De Angelis, 2010; Linebaugh, 2008; Midnight Notes, 1992), as well as through feminist (Mies, 2014; Federici, 2004) and post-colonial critiques (Spivak, 1988; Tuck and Yang, 2012), we contend that various forms of silence, when put to the task of commoning, can offer a useful approach to making other worlds within the Anthropocene.

Taking our cue from accounts of the Anthropocene that posit it as the expression and outcome of specific modes of accumulation - transformations of capitalism (Dyer-Witheford, 2015), reorganisations of so-called nature (Moore 2015) and the renewal of modes of colonial violence (Lewis and Maslin 2015) - we contend that silence is a crucial if overlooked aspect 
of commoning. In particular, we argue that staying with the 'trouble' of the Anthropocene (Haraway 2015) brings silence to the fore as a means of disrupting the allied processes of accumulation at work across these three sites. This is not because silence is any one thing: silence is not a singular practice to be taken up. Nor is it because all three are intimately bound up in the varied histories of the Anthropocene. Rather, it is through these three sites that silence most clearly troubles the call to heroic action that characterizes Anthropocenic discourse. We contend that by troubling the binaries of active/passive and culture/nature, silence produces the grounds for commoning in the present moment.

After setting out accounts of both commoning and silence as operative concepts, we turn to the regime of production referred to as cognitive capitalism, employing the writing of Paulo Virno and Franco Berardi to explore the conditions of an age in which mental and social affects and activities are repurposed as labour processes. Here we develop the first account of silence as praxis: as a refusal of communicative labour within cognitive capitalism. We argue that the refusal to participate or to speak disrupts existing modes of political and social agency that reproduce cognitive capitalism and its associated regimes of governance.

Turning to the mobilization of silence as a means to overcome human/non-human binaries through commoning, we secondly focus on Anthropocene ecologies. Here silence is understood as a means for becoming attentive to, and making space for, more-than-human forms of life. We are particularly concerned with asking how silence might help to expand commons beyond human interactions and experiences, into building relations across species boundaries. This attention to what is often ignored or made invisible by capital and the Anthropocene is further expanded in our third section, where silence is tied to the politics of representation though the violence of colonialism. We show how silence can be used to both 
push against the dominant regimes of speech as protest, engagement and response, at the same time as silencing the possibilities of who is heard, under what circumstances and how. At stake in the capacity to be seen and heard is more than just the capacity to act against the existing world: it is a matter of enduring the Anthropocene within neo/settler colonial regimes and the ruins of global capitalism (Povinelli, 2011).

Across these three sites it is the ambivalent nature of silence - as conjunctive absence and presence, excess and lack, activity and passivity - that provides a source of friction that we feel appropriate to the current milieu. In each of these three instances silence is posed as central to a multi-species, intersectional project of commoning. However, silence is not presented as one immutable concept or method: indeed as much as silence is crucial to resisting the brutalizing effects of global capitalism, so are visibility, speech and presence. We would suggest that it is precisely within the contested terrains where silence appears as impossible, as an abdication of responsibility or as a refusal of politics, that it assumes its most significant valence.

\section{Commoning}

In this paper we pursue the commons as a specific orientation to re/producing morethan-human relations. This counterposes the reading of the commons as a universalist human condition or shared substance that opposes, underlies or enables both contemporary capitalism and anti-capitalist revolt (Negri and Hardt, 2009; Zizek, 2009), and as a mobile concept to be detached from particular ways of labouring in the world (Berlant, 2016). Taking up the work of Peter Linebaugh (2008), we contend that commoning is always a situated practice. 
To emphasize the situated nature of commoning is not to speak of commons as though they were a natural resource. Following Linebaugh, we can articulate four characteristics of commoning as a practice. Firstly, commoning is always embedded in a particular ecology. The 'law of the land' is no sovereign law but more akin to the experimental scientist's obligation to follow the world as set out by Isabelle Stengers (2009). It is a question of asking what working within an ecology requires. Secondly, commoning involves particular labour processes. Common rights are labour rights, not property rights insofar as within a commons one works the land and does not hold it as a possession. Thirdly, commoning is always collective. Here we would add that the labouring collective is never merely human, but always more-than-human, involving animals, plants, resources, objects. Finally, commoning is defined in opposition not only to both state and capital, but also to their temporalities (2008:45).

As an oppositional practice, commoning is grounded in refusal. Silvia Federici argues that "no common is possible unless we refuse to base our life, our reproduction, on the suffering of others" (2011). The refusals and withdrawals of commoning are therefore "the first line of resistance to a life of enslavement" (ibid). However, commons are neither universal nor evenly distributed. The material grounds for commoning in the Anthropocene are shaped by the legacies of capitalism and colonialism, requiring recognition of the heterogeneity and incommensurability of people, experiences, and situations. Commons thus necessitate sustained, experimental engagements with translation and translatability, with "the coloniality of power and the resulting geopolitics of knowledge" (Mezzadra 2015: 217), as well as with the violence inherent to such processes (Solomon and Sakai 2007). The shift to regimes of cognitive capitalism also calls for a critical engagement with commoning insofar as such constituent practices risk producing non-market resources to be plundered by 
capitalist processes. As Massimo De Angelis argues, "capital, too, is promoting the commons in its own way" (2010 unpag). Furthermore, while commoning calls for a working with the more-than-human world, it in no way guarantees an expansion of the political community to include more-than-human agents and lives. Commoning thus requires a deep engagement with the refusals of the more-than-human world, not only in order to make the space to common, but also to deepen the process of commoning itself.

In this paper we instigate three propositions on silence as commoning. Rather than ask who should be silent, we establish silence as attentiveness to when one is being forced to speak; as a means for knowing when worlds require listening to; and as a matter of refusing to be recognized. We will suggest all three be considered as variations on the theme at the heart of the commons: namely, how do we make spaces to create other worlds?

\section{Silence as practice}

In a political context, silence has largely designated the evacuation of agency, voice and power, as ACT UP's declaration in the 1980s that silence = death powerfully illustrates. It has been associated with repression, a tool to enforce what is heard and what remains inaudible - "to be silenced" - and as a betrayal, a remaining silent or holding secret when it is disingenuous to do so: white silence in the face of police murder of Black people, Indigenous peoples and people of colour. The connotations of oppression, coercion and cowardice are entangled in the histories of silence as a political response. As such, silence has most conventionally been framed as passive and neglectful.

The theorizations of refusal and negation within much autonomist Marxist praxis trouble this identification of the political with the active (in action, in speech). The autonomist politics of refusal are not bound to the Arendtian politics of action, where politics 
works to confirm a political identity or human community. Rather, the novelty of the theorization of refusal within autonomist thought is that it constitutes a political practice precisely because it is grounded in the denial to reproduce the worker as an identity (Negri 1991). In refusing to reproduce oneself as a worker, one throws capital into crisis, as the latter requires that a worker both work and be reproduced as a worker (Federici 2012).

Feminist scholars such as Federici $(2004 ; 2012)$ and Maria Mies (2014) have extended these insights by articulating how reproductive labour forms a key site of struggle against capitalist value production. Political activity is constituted not only as the refusal to maintain or produce a particular public identity, but contests the very divisions of the public and private, reproduction and work that makes politics possible. Such contestation forms the basis for feminist critiques of the dyadic pairings of male/politics/active vs. female/nature/passive (Plumwood, 1993). Bringing together the work of Federici, Mies and Val Plumwood, it could be argued that the very constitution of the political has historically depended on the hierarchical pairing of active/passive insofar as passivity has laid the grounds for the exploitation of women, those colonized and the more-than-human worlds.

While refusal and silence are often theorized as the 'first step' in a constituent moment (Holloway, 2005), we are more interested in exploring what it would mean to stay with silence - to refuse the formation of silence as inaction as opposed to speech as action. This means taking it in its excess and its absence and holding fast to the moment of refusal as a moment of commoning. In doing so we emphasize that silence is not simply one thing or another, but many things, sometimes contradictory, sometimes confusing. At times, the act of speaking is a radical one; speech is necessary to become not only visible but also representable. Because of this, a certain level of analytical care is needed as the particularity of silence means it does not manifest loudly or clearly, but exists in-between. To that end we 
join silence with commoning in order to produce a grammar of silence. Just as commons are always particular commons, silences are always specific silences. How someone, or somebodies, should be silent, when, for what - these are questions resolvable only in the instance when silence is called for. The question of silence within cognitive capitalism, the extinction of the more-than-human world and resistance to persistent and renewed forms of neocolonialism all speak to particular spaces where silence can act as a commoning practice in the face of anthropogenic violence.

\section{Cognitive capitalism}

One of the strongest contributions of recent autonomist Marxist thought is the articulation of how language and autonomous activity form part of the basis for capitalist accumulation and neoliberal governance. This is exemplified in the work of Paulo Virno $(2004,2008)$ who contends that many of the qualities 'traditionally' associated with political and creative activity have come to be subsumed into capitalist production. For Virno, human capacities such as intellect, language, and emotions now operate as the foundations for capitalist accumulation, with "attitudes of the mind gain[ing] primary status as productive resources" (2004: 201).

At a time in which "social culture, contrasting imaginaries, expectations, and disappointments, loathing and solitude, all enter to modify the rhythm and pace of the productive process" as Franco Berardi (2007: 58-59) puts it, a refusal to enunciate interrupts the rapid translation, representation and appropriation of political and social energies and alliances within neoliberal paradigms. When participation is called for at every moment, when subjects are continually called upon to speak, to say what 'we' want or how 'we' feel, the question of silence presents itself as an act of refusal and sabotage. The key orientating 
question here is not so much 'who should be silent' but 'when are 'we' forced to speak'. Such a question illuminates those arrangements where silence can be most effective in undermining both capitalist accumulation and the managerial governance of the state.

Silence as an act of sabotage may also apply to radical political calls to action. Writing about the contemporary left, Berardi (2011) criticizes the attachment of activism to forms of mobilization and activity, which he identifies as locked to past modes of political activism. While for Berardi this provocation to withdrawal is tied to the collapse of modernist systems of organisation and collectivity (and thus to the exhaustion of the very possibility of politics), the point he makes folds into a broader argument on how common spaces, publics, and communication designate new terrains of contemporary production and the formation of labouring subjects (De Angelis 2010). Developing the argument further, we would suggest that withdrawal on this terrain is not a sign of failure or defeat but rather marks the limit of Arendtian notions of the political. Whereas Berardi sees activity and speech as seamlessly caught in a web of post-Fordist production and hence silence as the limit of political action, in returning to the early themes of autonomist Marxist praxis we can see such moments of 'passivity' as part of a longer genealogy of refusal where acts of passivity (refusals, go slows, wildcat strikes with no clear demands) function as positive negations by workers (Wright 2002).

A denial of speech outwardly is thus not a denial of agency, power or selfdetermination - in fact it may function as reclamation of the parameters of political constitution in a nonfigurative sense. Writing about the 2011 London protests in the wake of the racist police shooting of Mark Duggan, Peter Fleming commented on the striking power of the protestor's "withdrawal from the machinery of dialogue" (2013: 628). This was not an evacuation of sound from those participating, argued Fleming, but rather a strategic dismissal 
of the pressure for explanation. For Fleming, the protestors' refusals to offer cohesive justifications of their aims, demands and leaders suspended any kind of engagement with, and legitimation of, official discourse. While narratives of the events proliferated in the media, the refusal to form into easily definable groups, or to testify, was a way for participants to negate categorization by government and 'expert' bodies. Refusing to participate in the labour of communication was thus a refusal to participate in the regimes of communication endemic to capital. For Fleming (2013), the refusal of outward demands indicated a "postrecognition politics". Denial of speech in this sense was not a wholesale refusal of collective composition per se. Rather it was a means to challenge modes of participation and communication and forge other forms of social composition grounded in silence. It was the absence of participation, the absence of speech, that itself constituted the commons of ungovernability.

As in the protestor's outward silence, where cognitive capitalism transforms the grounds of the polis - language, action - into regimes of work, the autonomist notion of refusal suggests a means for breaking from this conflation, for building different kinds of resistant constellations. It is this difference that, given the role of human exceptionalism in creating the material condition of the Anthropocene (Crist, 2013), is fundamental to a reorientation towards the commons as the grounds for another life, one additionally attentive to the more-than-human participants in the construction of social worlds.

\section{Quiet Earth}

While much Anthropocenic discourse focuses on humanity, one of the key markers of this new epoch is the erasure and silencing of vast numbers of more-than-human beings. The extinction of other-than-human life makes for a quiet earth. Calls to act against the ecocidal 
violence of humanity are prefaced by injunctions to pay attention: to see, listen and feel the dyings (Kolbert, 2014). However, attentiveness demands silence. Silence, in this way, is one method for tracing encounters across human and non-human life forms.

Silence in Anthropocene ecologies does not denote an absence of humanity - it is not a call to return to the wild or some pre-historical state. We recognize that such a state is only ever the product of violent 'clearings' or works of enclosure that drive people out of the territories they inhabit. Rather, it works as a mode of active listening, one designed to draw the more-than-human 'background' (Plumwood 1993) into the foreground of thought. That is, it is a means of partially undoing the Modernist labour of producing 'nature' as a passive object. As such, this approach applies as much to the edgelands that weave through and around urban centres as it does to unfelled forests or unpopulated coastlines. The use of silence to foreground these more-than-human processes that are often taken for granted can play an active role in commoning with the more-than-human world.

Commons are made - they are particular regimes of production that require the activity of a range of actors as well as earth processes. The role of silence is to push to the front the more-than-human and inhuman processes with which one will common. To work a field of crops, to graze, to forage: all of these processes call for attention in order to see and hear ecologies unfold and move. Silence as a foundation of observation of the more-thanhuman and inhuman worlds has been often codified in a range of horticultural and craft practices (Papadopoulos, 2014), where care rather than appropriation forms the basis of a working-with the world (Bellacasa, 2012). Exemplary here is the practice of permaculture, a system of agriculture utilizing a philosophy of "working with rather than against nature; of protracted and thoughtful observation rather than protracted and thoughtless labor; and of looking at plants and animals in all their functions" (Mollison, 1991). Permaculture starts 
with an extended period of observation - of silence - in order to see the relationships and patterns at work within a particular ecological environment.

Yet while silence is necessary to common, the Anthropocene as a silencing of the more-than-human world compels us to ask another set of questions. What would it mean to take the extinction of more-than-human forms of life seriously in themselves? What would it look like to consider within political thought how current rising sea levels affect the erosion of sand and mangrove populations, that in turn diminish and move the habitats of sea life upon which island economies are reliant? How does silence enable a decentering of Modernist notions of humanity and a troubling of the heroic narrative of the Anthropocene?

The work of Bernie Krause (2013) illustrates the role human silence can play in enabling the reconstitution of more-than-human ecologies. Krause's work as an acoustic ecologist maps how human activity - logging, highways, pesticides and aircraft traffic drown out the sounds of the more-than-human world. Krause emphasizes these sounds, naming the specific chorus of calls, songs, and noises of a particular ecology as its biophony (ibid). The biophony of any given ecology is a central aspect of how an ecology organizes and reproduces itself. As a space of more-than-human communication, it forms the basis for complex communities, knitting together series of relationships and distinct acoustic niches. When this soundscape is disrupted, the ecology degrades leading to an unraveling of morethan-human forms of life. The breakdown in the biophony contributes to the long dyings of extinction. Krause documents not only the unravellings of life that take place through the disruptions of biophonies, but also how they can recover when humanity absents itself from an environment. His recordings suggest that our silence can operate as a means of making space for other forms of life to flourish. 
In this context, the struggle to exist stretches the concept of what Angela Davis calls an 'intersectionality of struggles' (2014: np) insofar as it challenges the implied sense that intersectional struggles converge around common concerns. Commoning at the edge of the extinction of the more-than-human world does not necessarily produce singular or coherent communities that include us. Rather, in considering how to build relations across otherness, without assimilating difference or demanding equivalence, commoning at the borderlines of extinction suggests the need to vacate space as a means to allow other worlds to flourish.

In other words, silence not only works to create the space to pay attention, to be attentive to what the world obliges subjects and bodies to do in order to common, but also crucially enables the more-than-human world to flourish on its own terms. The risk of positing silence solely within the framework of human commoning starting from within the ruins of Modernity (and its attendant notions of humanity) is that the instrumentalist logics of Anthropocenic discourse that celebrate breeding zoos and wildlife preserves is reproduced. A logic, it need be noted here, that also functions to reinforce the dyadic parings of male/politics/active vs. female/nature/passive (Plumwood, 1993), and as such reinforce the patriarchal and colonial ordering of the Anthropocene through a specific production of nature. In contrast then, the question of silence here is: how is the world being drowned out, and how can we make the space for the world to speak without us?

Commoning as a situated practice reminds us that there is no guaranteed common ground to resistance. An ethical comportment within the commons must leave space for nonaffirmation, for changing temporalities, for disagreeable desires, and still find some means of finding collective stakes and being alongside one another. This includes finding ways of attending to the "shadows of that which does not have, cannot have or does not want to have a political voice" (Stengers 2005: 996). 
1610

Defining the commons as materially situated suggests the need to be attentive to the uneven grounds of commoning: who can common, under what circumstances and to what extent. There is a growing body of literature exploring the intersection between cognitive capitalism and neocolonial violence, particularly as relates to the technosphere's production and maintenance (Dyer-Witheford, 2015). Beyond the violence it imposes on bodies, ecologies and forms of life however, the Anthropocene can itself be seen an outcome of European colonialism, inscribing colonial violence in the planet's geochemistry and atmospheric dynamics (Lewis and Maslin, 2015; Todd, 2015). Dating the 'golden spike' of the Anthropocene to 1610, Simon Lewis and Mark Maslin make the deliberate absence of colonized peoples the marker of the current geological epoch. When faced with such a forced silencing, how can silence as a necessary mode of commoning in the Anthropocene be maintained, especially when, in the context of neo/colonial violence, it often denotes not only the destruction of whole peoples and cultural legacies, but also complicity with colonial forces? Moreover, how do we engage with commoning as a practice when the ability to common is itself an uneven product of 500 years of colonial violence, dispossession and genocide?

The complex ways in which silence has operated within neo/colonial spaces require us to pay attention to the activity of empowering speech as the articulation of agency within politics (Spivak 1988). Yet while the subaltern attainment of 'voice' can be seen as critical for political equality, the acquirement of political recognition is not without its dangers. Aimee Rowe and Sheena Malhotra argue that "the figure of the subaltern gaining voice captures the political imaginary, shifting the focus away from the labor that might be demanded of those in positions of power to learn to listen to subaltern inscriptions - those 
modes of expression that are often interpreted as "silence"" (2013: 2). No less problematic is the production of modes of representation and communication that serve to reinforce neo/colonial governance. As Frantz Fanon argues, in times of anti-colonial revolt the emergence of people willing to speak "in the name of the silenced nation" (2005) is welcomed by the ruling bureaucracy "with open arms" as a means of re-establishing control over an ungovernable populace. Silence is thus ambivalent in this context, suggesting the need to ask not only who forces one to be quiet and to disappear, but also who would speak on one's behalf.

Alongside the clear role for speech (and listening) in post/colonial contexts, there is much de/colonial work that considers silence as an active and self-determined stance against neo- and settler colonial regimes (Simpson 2009; Tuck and Yang 2014). Silence considered as anti-colonial resistance manifests in a similar way as it does within the circuits of cognitive capitalism - as a refusal to reproduce neo- and settler colonial social relations, a refusal to be governable, or to participate in 'development'.

The ability to be 'heard' via representatives and to be governable often hinges on how colonized peoples come to be counted. As such, it is the refusal to be counted - via representatives, through direct participation in government programs or quite literally by refusing to be counted through government census - that constitutes the basis for the active silence of colonized peoples. This is evidenced in the on-going debates within the First Nation peoples in the occupied territory of Canada over whether or not Indigenous peoples should vote in Federal elections, with some contending participation in these elections undermines Indigenous sovereignty, and others proposing it as a useful tactic to secure better grounds for future negotiations (Sayers, 2015). As Judith Sayers, former chief of the Hupacasath First Nation argues, "why would you want to vote for a government that 
continually imposes legislation and policies that do not provide for the advancement of First Nations?" (ibid). This suggests that to participate in choosing a political representative as a First Nations person is in effect to choose an 'un-representative' to enact legislation and policies that actively undermine not only the capacity of First Nations peoples to survive as Indigenous, but the very notion of autonomy inscribed in First Nations treaties itself.

The imposition of citizenship as well as destructive or assimilationist policies often rests on synoptic mechanisms of measurement. In Canada the collection of census data has had profound impacts on First Nations peoples, and as such First Nations peoples have frequently resisted and refused to co-operate with census takers. Such refusal has taken a variety of forms, from physically absenting oneself during census counts (going 'missing'), to refusing to answer census questions and remaining silent, to driving census-takers out of Indigenous territories (Hubner, 2007). The refusal to be representable in this latter instance joins Indigenous struggles against governability to both peasant insurrections against census takers (i.e., Taylor, 1979: 127) and broader revolts that posit a general ungovernablity as found in recent urban riots (Clover, 2016).

It is here that the clearest link between the strategies of refusal within the circuits of cognitive capitalism and decolonial struggles exists. Participation, in both instances, risks incorporation. As such commoning, in the neo/colonial context, can appear as both a potential site of resistance and of incorporation. Commons situated in the margins of urban peripheries can function as non-market institutions that work to sustain involvement in informal or formal waged labour, effectively enabling the reproduction of capitalist social relations where capital is unable or unwilling to meet the cost of reproducing labour power. As Federici has pointed out, resistant commoning and (particularly Indigenous women's) subsistence practices developed to maintain relations of commons and evade the logics of 
commodification, have increasingly been monetised by NGOs and the World Bank under the rubrics of sustainability and greenwashing (2015: 208). Similarly, analyses of the black radical tradition in Europe and the USA emphasize how practices of commoning and cooperative organizing amongst black communities have been exposed to expropriation and marketisation by racialised capitalism (Robinson 1983; Nembhard 2014). Commoning, in these instances, can work to reinforce regimes of accumulation and governance rather than facilitate a break from such neo/colonial orders.

The question then is how to common against such incorporations. Or, perhaps more pointedly, the question might be: are silence as refusal and commoning as autonomy counterposed in this instance? Silence, in a colonial context, reminds us that de/colonization is not a metaphor, it is a question of territory (Tuck and Yang, 2012). Silence here can denote a space of action, a silent withdrawal through commoning as a means of retaking hold of occupied land. There is a crucial element of commoning as reterritorialisation, where reterritorialisation is an antagonistic claim to land that fractures the conception of the earth as a globe. The heterogeneous temporalities of decolonial commoning contest the "sense of planet" (Heise, 2008) produced through the vast machines that catalogue and chart the earth. The object produced through these machines - the 'global environment' - is a means of pursuing modes of capitalist and neo/colonial governance that seek to overcome the varied 'frictions' of anti- and decolonial action (Tsing, 2005). As commoning is always bound to the specific legacies and capacities of the territories in which it is embedded, it is opposed to managerial notions of the global commons, just as it is opposed to the representative politics of NGOs and institutional political forms.

Perhaps one of the most manifest sites of conflict around the construction of the global environment as an object of management is that of the national park - often a site of 
'world heritage value' or of global importance. Such places play a crucial role in conservation praxis as the mechanisms of international biodiversity governance, and hold a key discursive and symbolic role in the production of the idea that there is a singular environment that spans the globe. The creation of national parks - and with them the very notion of wilderness that underpins much global environmental thinking - is achieved through the dispossession of millions of Indigenous and marginal peoples, creating a reported 130 million 'conservation' refugees (Survival International, 2014). Such projects of ecological cleansing do not go uncontested: revolts in India have halted evictions of tribal peoples from a number of wildlife reserves (ibid), and members of the Waorani tribe have violently resisted eviction from Ecuador's Yasuni National Park (ibid).

In this latter instance, commoning stands as a means of maintaining a hold over a territory, as something that is destroyed through conservation enclosures in order to make room for the kinds of picturesque 'environments' that populate narrations of the Anthropocene. From the Amazon to coastal parks, it is the future visions of these spaces disappearing that form the affective underpinning to Anthropocenic tales of catastrophe. Commoning against these conservation spaces joins with other modes of refusal to be governed as a means of resisting the production of forms of global stewardship as championed by supporters of the Anthropocene project (Steffen et al 2011).

The refusal to be counted, to speak, joins with the refusal to make way for national (and global) projects in a process of ungovernablity. To withdraw territory from the nationstate, or to contest the capacity of the nation-state to govern territory via commoning is a means of making silence into a de/colonising device, one that works through the refusal of representation and incorporation. By making territory and peoples unincorporable through 
silence, de/colonial struggles are able to frustrate projects of neo/colonial governance, opening the way for a reoccupation of their territories via commoning.

\section{Conclusion}

Faced with mass extinctions, runaway climate change, disappearing ice sheets and rising sea levels, silence at first glance manifests as a denial of the Anthropocene, a refusal to respond decisively to the global environmental crisis. Yet the call to action, to heroically remake the earth through geoengineering or to institute a form of global environmental governance, itself confuses the substance of the Anthropocene with its resolution. The Anthropocene is the expression and outcome of specific modes of accumulation transformations of capitalism (Dyer-Witheford, 2015), reorganisations of so-called nature (Moore 2015) and the renewal of modes of colonial violence (Lewis and Maslin 2015). It not only names a historical event, but signals an on-going process that produces nature-as-object on one hand and an intrepid global agent - humanity - on the other.

Silence as a commoning practice refuses the heroic narrative that underpins Anthropocenic discourse and its logic of global stewardship. In an epoch in which opinion, voice and communication reach their velocity as political response, silence assumes its most significant valence. The Anthropocene is the outcome of 500 years of dispossession, capitalist accumulation and neo/colonial globalization. The fabrication of the biosphere as a global environment continues this project of incorporation to better manage the earth. In this context, silence marks a refusal to reproduce existing Anthropocenic social relations, and becomes productive of the absence required in order to make other worlds possible.

Commoning is the means here of both resisting and constituting otherwise against this global ordering. Silence enables commoning as it opens space to produce other forms of life. 
The refusal to participate or speak works to disrupt existing modes of governance, processes of capitalist accumulation and the ordering of national territories. The refusal to be incorporable and governable produces an absence of governance enabling commoning to take place. At the same time, the silence produced through refusal challenges human exceptionalism and holds space for the more-than-human. As such, it creates the grounds for particular expanded notions of community or alliance, bound to specific ecological processes and more-than-human agents. Silence as a refusal to reproduce oneself as a worker, as a subject and as, ultimately, human, allows for other autonomous forms of life and processes of social reproduction unhinged from the exhaustive governmental projects of late liberalism (Povinelli, 2011) to occur.

The practices of silence and commoning are not universally applicable, nor grounded in a shared social condition. The material foundations upon which commoning takes place and the political logics into which silence enters necessitates a situated application. There are times when commoning reinforces accumulation, when silence equates with complicity and violence. As liminal practices that engender the movement from one social regime to another, the question is not one of universal application. Rather, silence and commoning enter into political calculus through the question of how to make space for other forms of life; or, perhaps finally, how to make the current regimes of life ungovernable.

\section{References}

Beckett Samuel. 1967. No's Knife. London: Calder and Boyars.

Bellacasa, Maria Puig de la. 2012. "Nothing comes without its world': thinking with care" Sociological Review. 60, no. 2: 197-216.

Berardi, Franco. 2007. "Technology and Knowledge in a Universe of Indetermination." Translated by Giuseppina Mecchia. SubStance 112, 36, no. 1: 57-74.

Berardi, Franco. 2011 After the Future. Oakland and Edinburgh: AK Press. 
Berlant, L. 2016. "The commons: Infrastructures for troubling times" Environment and Planning D: Society and Space 34, no.3: 393-419

Caffentzis, G. 2013. In Letters of Blood and Fire: Work, Machines, and the Crisis of Capitalism. Oakland: PM Press.

Clark, Nigel. 2011. Inhuman Nature: Sociable Life on a Dynamic Planet. London: Sage.

Clover, J. 2016. Riot. Strike. Riot: The New Era of Uprisings. London: Verso.

Crist, Eileen. 2013. "On the Poverty of Our Nomenclature" Environmental Humanities 3: 12947.

Davis, Angela. 2014. "Transnational Solidarities: Resisting Racism, Genocide and Settler Colonialism" Paper presented at Hrant Dink Memorial Lecture, Bosphorous University, Istanbul, 9 January.

De Angelis, Massimo. 2010. "On the Commons: A public Interview with Massimo De Angelis and Stavros Stavrides.” E Flux http://www.e-flux.com/journal/on-the-commons-apublicinterview-with-massimo-de-angelis-and-stavros-stavrides/

Dyer-Witheford, Nick. 2015. Cyber-Proletariat: Global labour in the digital vortex. Chicago: The University of Chicago Press.

Fanon, Frantz. 2005. The Wretched of the Earth. New York: Grove Press.

Federici, Silvia. 2004. Caliban and the Witch: Women, The Body and Primitive Accumulation. New York: Autonomedia.

Federici, Silvia. 2011. "Feminism and the politics of the commons" The Commoner. Other articles in common edition. http://www.commoner.org.uk/?p=113

Federici, Silvia. 2012. Revolution at Point Zero: Housework, Reproduction and Feminist Struggle. Oakland and New York: PM Press.

Federici, Silvia. 2015. "Reenchanting the World: Technology, the Body and the Construction of the Commons." In The Anomie of the Earth: Philosophy, Politics and Autonomy on Europe and the Americas, edited by Federico Luisetti, John Pickles and Wilson Kaiser, 202-215. Durham and London: Duke University Press.

Federici, Silvia and Caffentzis, George. 2012. "Commons Against and Beyond Capitalism." Upping the Anti: A Journal of Theory and Action 15: 83-97

Fleming, Peter. 2013. "Common as Silence.” Ephemera 13, no. 3: 627-640.

Guattari, F. 2000. The Three Ecologies. London: The Athlone Press 
Haraway, Donna. 2015. "Anthropocene, Capitalocene, Plantationocene, Chthulucene: Making Kin.” Environmental Humanities 6: 159-165.

Heise, U. 2008. Sense of Place and Sense of Planet: The Environmental Imagination of the Global. Oxford: Oxford University Press.

Holloway, John. 2005. Changing the world without taking power. London: Pluto Press

Hubner, Brian Edward. 2007. ““'This is the Whiteman's Law”: Aboriginal resistance, bureaucratic change and the Census of Canada, 1830-2006". Archival Science, 7, no.3: 195206

Kolbert, Elizabeth. 2014. The Sixth Extinction: An Unnatural History. London: Bloomsbury

Krause, Bernie. 2013. The Great Animal Orchestra: Finding the Origins of Music in the World's Wild Places. London: Profile Books

Lewis, S and Maslin, M. 2015. “Defining the Anthropocene.” Nature 519, no. 7542: 171-180.

Linebaugh, Peter. 2008 The Magna Carta Manifesto: Liberties and Commons for All. Berkeley and Los Angeles: University of California Press.

Mezzadra, Sandro. 2015. "Afterword: Resonance of the Common." In The Anomie of the Earth: Philosophy, Politics and Autonomy on Europe and the Americas, edited by Federico Luisetti, John Pickles and Wilson Kaiser, 215-227. Durham and London: Duke University Press.

Midnight Notes. 1992. 'The New Enclosures' Midnight Oil: Work, Energy, War, 1973 - 1992. New York: Autonomedia.

Mies, Maria. 2014. Patriarchy and Accumulation on a World Scale: Women in the International Division of Labour. Third Edition. London: Zed Books.

Mollison, B. 1991. Introduction to permaculture. Tasmania, Australia: Tagari.

Moore, Jason W. 2015. Capitalism in the Web of Life: Ecology and the Accumulation of Capital. New York: Verso.

Negri, A. 1991. Marx beyond Marx: Lessons on the Grundrisse. New York: Autonomedia.

Negri, A. Hardt, M. 2009. Commonwealth. New York: Harvard University Press

Nembhard, Jessica G. 2014. Collective Courage: A History of African American Cooperative Economic Thought and Practice. Pennsylvania: Pennsylvania State University Press. 
Papadopoulos, Dimitris. 2014. "Politics of Matter: Justice and Organisation in Technoscience". Social Epistemology: A Journal of Knowledge, Culture and Policy. 28, no. 1: $70-85$

Plumwood, V. 1993. Feminism and the mastery of nature. London: Routledge.

Povinelli, E. 2011. Economies of abandonment: Social Belonging and Endurance in Late Liberalism. London: Duke University Press.

Rich, Adrienne. 1978. The Dream of a Common Language: Poems 1974-1977. New York: Norton.

Robinson, Cedric J. 1983. Black Marxism: The Making of the Black Radical Tradition. London: Zed.

Rowe, Aimee C. and Malhotra, Sheena. 2013. "Introduction: Still the Silence: Feminist Reflections at the Edges of Sound" In Silence, Feminism, Power Reflections at the Edges of Sound, edited by Sheena Malhotra and Aimee C. Rowe, 1-22. New York: Palgrave McMillan.

Sayer, Judith. 2015. "To Vote or Not to Vote? Chief's Dilemma Shared by Many First Nations" The Tyee. http://thetyee.ca/Opinion/2015/09/05/Vote-Dilemma-First-Nations/

Simpson, Audra. 2007. “On Ethnographic Refusal: Indigeneity, 'Voice' and Colonial Citizenship." Junctures 9: 67-80.

Solomon, Jon and Sakai, Naoki. 2007. "Translation, Violence, and the Heterolingual Intimacy." EIPCP http://eipcp.net/transversal/1107/solomon/en

Spivak, Gayatri C. 1988. "Can the Subaltern Speak." In Marxism and the Interpretation of Culture, edited by Cary Nelson and Lawrence Grossberg, 271-313. Urbana: University of Illinois Press.

Steffen, Will., Persson, Asa., Deutsch, Lisa., Zalasiewicz, Jan., Williams, Mark., Richardson, Katherine., Crumley, Carole., Crutzen, Paul., Folke, Carl., Gordon, Line., Molina, Mario., Ramanathan, Veerabhadran., Rockström, Johan., Scheffer, Marten., Schellnhuber Hans J., Svedin, Uno. 2011. "The Anthropocene: From Global Change to Planetary Stewardship", Ambio 40, no.7. 739-761

Stengers, Isabelle. 2005. “The Cosmopolitical Proposal.” In Making Things Public: Atmospheres of Democracy, edited by Bruno Latour and Peter Weibel, 994-1003. Cambridge: MIT Press.

Stengers, Isabelle. 2009. The Invention of Modern Science. London: University of Minnesota Press.

Survival International. 2014. Parks need peoples. London: Survival International 
Taylor, William B. 1979. Drinking, Homicide, and Rebellion in Colonial Mexican Villages. Stanford: Stanford University Press

Todd, Zoe. 2015. "Indigenizing the Anthropocene". In Art in the Anthropocene: Encounters Among Aesthetics, Politics, Environments and Epistemologies. Eds Davis, Heather. Turpin, Etienne. London: Open Humanities Press.

Tsing, A. 2005. Friction: An Ethnography of Global Connection. Princeton: Princeton University Press

Tuck, Eve and Yang, K. Wayne. 2012. "Decolonization is not a metaphor", Decolonization: Indigeneity, Education \& Society 1, no.1:1-40.

Tuck, Eve and Yang, K. Wayne. 2014. "R-words: Refusing Research.” In Humanizing Research: Decolonizing Qualitative Inquiry with Youth and Communities, edited by Paris Django and Maisha T. Winn, 223-248. Thousand Oaks: SAGE.

Virno, Paolo 2004. A Grammar of the Multitude. Los Angeles and New York: Semiotext(e).

Virno, Paolo. 2008. Multitude: Between Innovation and Negation. Translated by Isabella Bertoletti, James Cascaito, and Andrea Casson. Los Angeles: Semiotext(e).

Wright, Steve. 2002. Storming Heaven: Class Composition and Struture in Italian Autonomist Marxism. London: Pluto Press.

44, no. 7: 2228-2231.

Zizek, S. 2009. First as tragedy, then as farce. London: Verso.

The authors would like to thank Sara Nelson, Bruce Braun and Camille Barbagallo for their invaluable comments on drafts of this paper. 